\title{
Unique Image Characteristics of an Occipital Primary Chondroblastic Osteosarcoma: A Rare Case Report and a Brief Literature Review
}

\author{
Xin $\mathrm{He}^{1}$ Tingting Yuan ${ }^{1}$ Yuzhu Yan ${ }^{1}$ jinlu Yu ${ }^{2}$ \\ ${ }^{1}$ Department of Radiology, the First Affiliated Hospital of Jilin \\ University, Changchun, China \\ 2 Department of Neurosurgery, the First Affiliated Hospital of Jilin \\ University, Changchun, China
}

\author{
Dan Tong ${ }^{1}$
}

J Neurol Surg Rep 2017;78:e77-e80.

\author{
Abstract \\ Keywords \\ - chondroblastic \\ osteosarcoma \\ - occipital bone \\ - skull base \\ - computed \\ tomography \\ - magnetic resonance \\ imaging
}

\author{
Address for correspondence Dan Tong, PhD, Department of \\ Radiology, the First Affiliated Hospital of Jilin University, 71 Xinmin \\ Avenue, Changchun, Jilin, 130021, China \\ (e-mail: tongdan2012@126.com).
}

\section{Introduction}

Osteosarcoma (OS) develops most frequently in the extremities, and it is the most common histologic form of the primary bone cancers. ${ }^{1,2}$ Head and neck OSs are rare, comprising only 6 to $10 \%$ of all OSs. ${ }^{3,4}$ They typically present in the third or fourth decade of life and comprise only $1 \%$ of all pediatric head and neck malignancies. The most common craniofacial sites affected by OSs are the mandible and maxilla, followed by the calvaria and then the skull base. ${ }^{4-6}$ On cytology, OS can be divided into several pathologic types, including the pleomorphic, epithelioid, chondroblastic, small cell, mixed, and osteoclast-like giant cell types. ${ }^{6}$ In head and neck OSs, the chondroblastic type occurs most frequently. ${ }^{7}$

Skull base OSs can be challenging to resect and an aggressive surgical approach can result in poor cosmetic outcome. ${ }^{8}$ Imaging plays a crucial role in the diagnosis of each subtype of OS and ultimately in patients' survival because the diagnosis is based on a combination of histopathologic and imaging features. The therapeutic options and prognoses for different types of OS differ from each other, so correct diagnosis is essential. ${ }^{9,10}$ Magnetic resonance imaging (MRI) or computed tomographic (CT) scan should be used to assess the extent of the primary tumor. ${ }^{11}$

In this case report, we describe a pediatric patient of occipital OS of the chondroblastic type. The chondroblastic type of OS has an exceedingly poor outcome. ${ }^{12}$ However, the detailed imaging description of such cases have not been reported in the previous literatures. We present the CT, MRI, and enhanced MRI features of this case, followed by a brief review of the related cases reported in the previous literatures

\section{Case Report}

A 9-year-old boy was admitted to our hospital with a major complaint of a growing mass on his head. Physical examination found a firm and tough mass on the right occipital that showed no tenderness upon palpation. CT scan showed the right occipital bone to be irregularly thickened with fluffy and cloudy calcification, with a mass deriving from the received

November 15, 2016 accepted after revision March 4, 2017
DOI http://dx.doi.org/ 10.1055/s-0037-1601876. ISSN 2193-6366.
๑) 2017 Georg Thieme Verlag KG
Stuttgart • New York

License terms

((1) $\circledast$ 
internal occipital protuberance extending toward the basilar part of the occipital bone, invading the neighboring jugular foramen, the sublingual neural tube, and the mamillary process. On MRI, the lesion was $4.5-\times 5.5-\times 6.5-\mathrm{cm}$ in size with calcifications areas of hypointensity in T1- and heterogeneous in T2-weighted series. Contrast MRI showed peripheral and septal enhancement in the interior side of the tumor (-Fig. 1). Significant mass effect was present, distorting the cerebellar hemisphere, pons, and the forth ventricle, which led to hydrocephalus, and the oppression of the sigmoid sinus and the transverse sinus. Histopathology examination reported lace-like osteoid material abutting

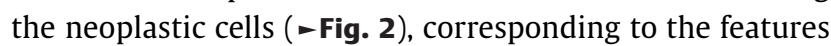
of chondroblastic OS, and occipital bone chondroblastic OS was the final definitive diagnosis. A subtotal resection of the tumor was performed followed by radiation therapy. The patient died after half a year of local recurrence.

\section{Discussion}

Craniofacial OSs are rare. They typically present in the third or fourth decade of life, account for fewer than $5 \%$ of OSs in children, and comprise only $1 \%$ of all pediatric head and neck malignancies. The most common craniofacial sites are the mandible and maxilla, followed by the calvaria and then the skull base. ${ }^{13-15}$ Our case in the right occipital bone of skull

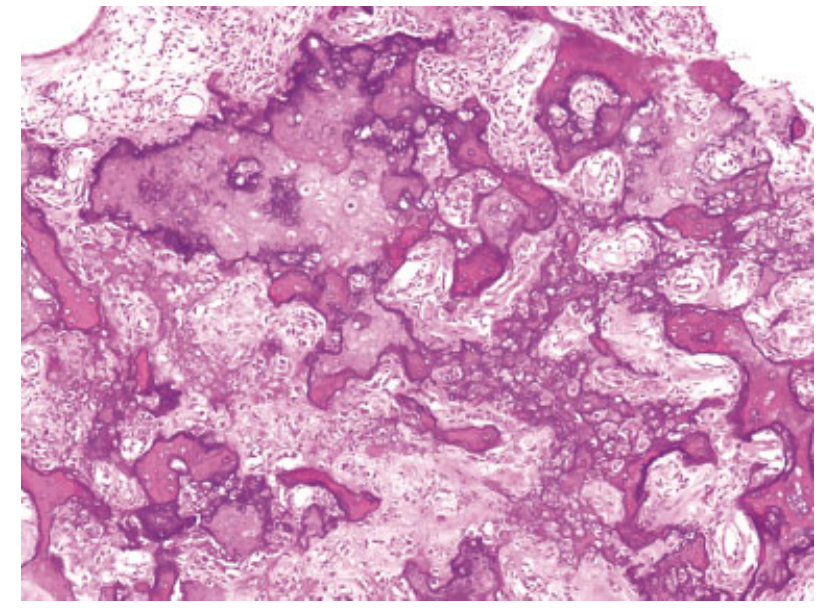

Fig. 2 Histopathologic examination (hematoxylin and eosin, $\times 200$ ) shows lace-like osteoid material abutting the neoplastic cells.

base is a very rare location. A search of the English language literature revealed 22 cranial OSs previously reported in children (-Table 1): 12 calvarial tumors and 10 tumors of the skull base. The mean age of the pediatric patients with cranial OS was 12.2 years old in this table. The patient in our case suffered at a younger age. On cytology, OS can be divided into pleomorphic, epithelioid, chondroblastic, small cell,
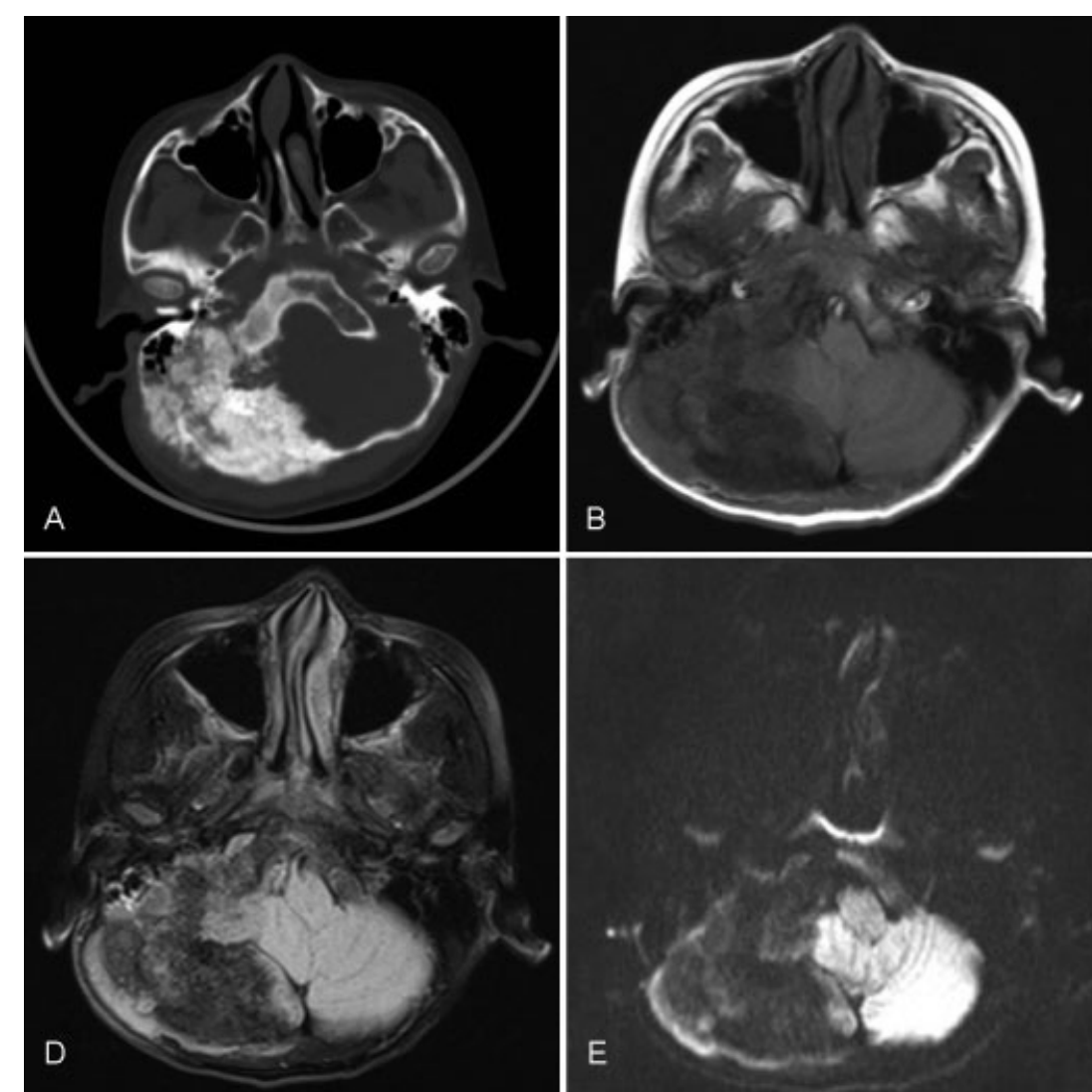

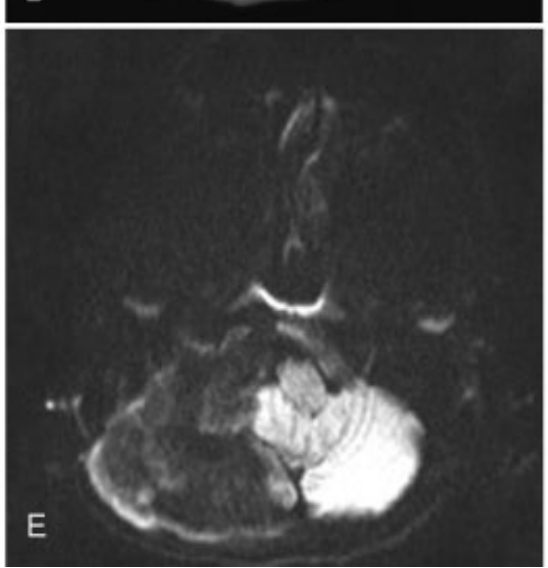

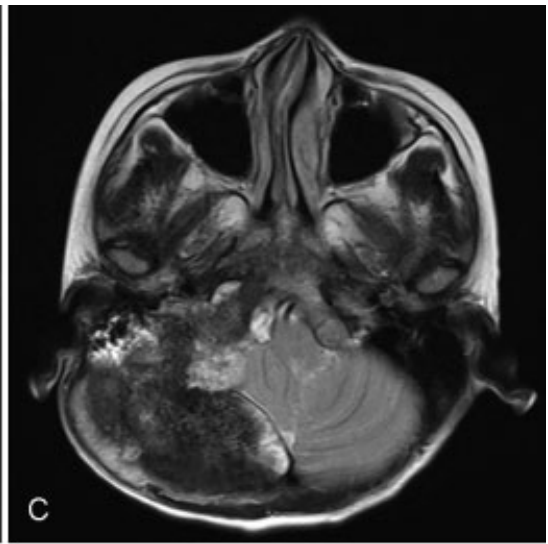

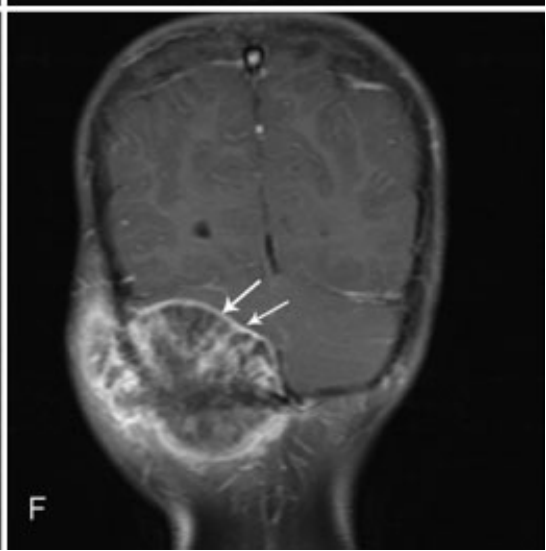

Fig. 1 (A) Computed tomography of the skull shows fluffy calcification. (B) T1-weighted image shows a 4- $\times 8-\times 10-\mathrm{cm}$ mass lesion, isointense to the skull. (C, D) The mass is hypointense in most areas in the T2-weighted series, with focal high signals in the T2-weighted series and reduced signal in FLAIR series. (E) In Gd-enhanced MRI, most areas show no enhancement or heterogeneous enhancement, with peripheral and atypical septal enhancement on the coronal plane (white arrows). (F) No hyperintensity was observed in both intra- and peritumoral areas in the DWI series. 
Table 1 Summary of previously reported cases of calvarial and skull base osteosarcomas in pediatric patients

\begin{tabular}{|c|c|c|c|c|c|c|}
\hline Author and year & $\begin{array}{l}\text { Age at } \\
\text { diagnosis }\end{array}$ & Location & $\begin{array}{l}\text { Extent of } \\
\text { resection }\end{array}$ & $\begin{array}{l}\text { Adjuvant } \\
\text { therapy }\end{array}$ & Follow-up & Outcome \\
\hline Garland, 1945 & $17, \mathrm{M}$ & Occipital & NR & RT & NR & NR \\
\hline Reddy et al, 1973 & $8, \mathrm{~F}$ & Occipital & Biopsy & RT & NR & Dead, progressive disease \\
\hline $\begin{array}{l}\text { Goodman and } \\
\text { McMaster, } 1976\end{array}$ & $15, F$ & Parietal-occipital & NR & $\begin{array}{l}\text { Chemotherapy } \\
\text { and RT }\end{array}$ & 6 & Alive, disease free \\
\hline Wang et al, 1981 & $17, \mathrm{M}$ & $\begin{array}{l}\text { Frontal-parietal- } \\
\text { occipital }\end{array}$ & NR & RT & 6 & Dead, progressive disease \\
\hline Benson et al, 1984 & $11, \mathrm{M}$ & Frontal & NR & Chemotherapy & 12 & Alive, disease status \\
\hline Sundaresan et al, 1985 & $\begin{array}{l}11, \mathrm{M} \\
13, \mathrm{~F}\end{array}$ & $\begin{array}{l}\text { Parietal } \\
\text { Skull base }\end{array}$ & $\begin{array}{l}\text { STR } \\
\text { STR }\end{array}$ & $\begin{array}{l}\text { Chemotherapy } \\
\text { Chemotherapy }\end{array}$ & $\begin{array}{l}36 \\
66\end{array}$ & $\begin{array}{l}\text { Alive, progressive disease } \\
\text { Alive, disease free }\end{array}$ \\
\hline Kornreich et al, 1988 & $12, \mathrm{~F}$ & Parietal & NR & Chemotherapy & 144 & Alive, disease free \\
\hline Mark et al, 1991 & $14, \mathrm{M}$ & Anterior skull base & NR & $\begin{array}{l}\text { Chemotherapy } \\
\text { and RT }\end{array}$ & 12 & Dead, progressive disease \\
\hline Shramek et al, 1992 & $8, \mathrm{M}$ & Parietal-occipital & GTR & $\begin{array}{l}\text { Chemotherapy } \\
\text { and RT }\end{array}$ & 16 & Alive, progressive disease \\
\hline Salvati et al., 1993 & $11, \mathrm{M}$ & Frontal-temporal & STR & RT & 9 & Dead, progressive disease \\
\hline Chander et al, 2003 & $15, F$ & Frontal & GTR & NR & NR & NR \\
\hline Author and Year & $\begin{array}{l}\text { Age at } \\
\text { diagnosis }\end{array}$ & Location & $\begin{array}{l}\text { Extent of } \\
\text { resection }\end{array}$ & $\begin{array}{l}\text { Adjuvant } \\
\text { therapy }\end{array}$ & Follow-up & Outcome \\
\hline Ellison et al, 1996 & $11, F$ & Skull base & STR & $\begin{array}{l}\text { Chemotherapy } \\
\text { and RT }\end{array}$ & NR & NR \\
\hline Gadwal et al, 2001 & $\begin{array}{l}9, \mathrm{M} \\
1, \mathrm{M}\end{array}$ & $\begin{array}{l}\text { Sphenoid } \\
\text { Sphenoid }\end{array}$ & $\begin{array}{l}\text { NR } \\
\text { NR }\end{array}$ & $\begin{array}{l}\text { RT } \\
\text { NR }\end{array}$ & $\begin{array}{l}9 \\
\mathrm{NR}\end{array}$ & $\begin{array}{l}\text { Dead, progressive disease } \\
\text { NR }\end{array}$ \\
\hline Chennupati et al, 2008 & $14, F$ & Skull base & Biopsy & $\begin{array}{l}\text { Chemotherapy } \\
\text { and RT }\end{array}$ & 12 & Alive, progressive disease \\
\hline Kirby et al, 2011 & $16, \mathrm{M}$ & Parietal & GTR & Chemotherapy & 5 & Alive, disease free \\
\hline Oakley et al, 2011 & $15, \mathrm{M}$ & Anterior skull base & GTR & Chemotherapy & NR & NR \\
\hline Ohno et al, 2011 & $14, F$ & Anterior skull base & STR & Chemotherapy & 26 & Dead, progressive disease \\
\hline Meel et al, 2012 & $10, \mathrm{M}$ & Sphenoid & Biopsy & $\begin{array}{l}\text { Chemotherapy } \\
\text { and RT }\end{array}$ & 18 & alive, disease free \\
\hline Caroline et al, 2014 & $\begin{array}{l}14, \mathrm{M} \\
12, \mathrm{M}\end{array}$ & Parietal skull base & $\begin{array}{l}\text { GTR } \\
\text { GTR }\end{array}$ & $\begin{array}{l}\text { Chemotherapy } \\
\text { Chemotherapy }\end{array}$ & $\begin{array}{l}16 \\
12\end{array}$ & Alive, disease free \\
\hline He et al, 2016 & $9, M$ & Occipital & STR & $\begin{array}{l}\text { Chemotherapy } \\
\text { and RT }\end{array}$ & 6 & Dead, progressive disease \\
\hline
\end{tabular}

Abbreviations: GTR, gross total resection; NR, not reported; RT, radiation therapy; STR, subtotal resection.

mixed, and osteoclast-like giant cell types. ${ }^{6}$ Our case is a chondroblastic subtype, which occurs most frequently in head and neck OSs.

The etiology of OS is unknown, but the major risk factors for development of OS in craniofacial bones may be similar to those of the long skeletal bones, consisting of exposure to radiation, retinoblastoma, Li-Fraumeni syndrome, and Paget's disease. The skull is a favored site for OS arising out of Paget's disease. Other bone abnormalities, such as fibrous dysplasia, multiple osteochondromatosis, chronic osteomyelitis, myositis ossificans, and trauma, have also been proposed as risk factors. ${ }^{7,15,16}$ The presenting symptoms varied with the location of the tumors. The maxillary or cranial lesions usually produced no pain, which was in accordance with our case; however, mandibular tumors frequently presented with focal painful swelling. ${ }^{17,18}$ Other common presenting symptoms include headache, cranial nerve palsies, exophthalmos, and visual impairment due to different location of the tumor. ${ }^{5,13}$
CT best demonstrates tumor mineralization, especially when minimal, and it is usually able to demonstrate tumor extension into the soft tissues. Hemorrhage, necrosis, and unmineralized, chondroblastic, or fibroblastic components of the tumor will appear as areas of low attenuation on CT if present. Unlike any other conventional OSs, we see fluffy calcification in our case, and we believe it is a characteristic of OS. The osteoblastic subtype is most common with nearly $90 \%$ containing variable amounts of cloudlike opacities. ${ }^{19}$ Bose $^{20}$ reported an osteoblastic OS that appears as a large soft tissue density mass with a few bony densities. Compared with our case, the soft tissue mass is prominent and the calcification is less and diffuse.

MRI is the preferred modality for locally staging OS, and it should be performed before percutaneous biopsy because it can help identify areas of viable tumor and mineralized matrix. In our case of gadolinium (Gd)-enhanced MRI, we found no enhancement or heterogeneous enhancement in most areas of the tumor, with septonodular and rim enhancement, which is 
in in accordance with the current literature. Areas that demonstrate either a heterogeneous enhancement pattern or lack enhancement are the preferred sites for biopsy because they are more likely to contain both chondroid and osteoid elements that are necessary for the correct diagnosis. ${ }^{21,22}$ Chondrosarcomas shows similar image characteristic, but they occur in an older age with a mean age of 57 years old. DWI can also help identify chondroblastic OS. Chondroblastic OSs also have significantly higher minimum and maximum apparent diffusion coefficient (ADC) values compared with other conventional OS subtypes, but they have a lower minimum ADC and similar maximum ADC value compared with chondrosarcoma. 23

Skull base OSs can be challenging to resect, and an aggressive surgical approach can result in poor cosmetic outcome. Thus, skull base tumors have a poorer prognosis than mandibular or maxillary tumors. ${ }^{3}$ Complete surgical excision is the mainstay of treatment of the primary tumor. Local recurrence is the main reason of treatment failure and mortality in head and neck OSs. Positive margins and a high tumor grade correlate with a statistically significant decrease in survival. ${ }^{11}$ In our case, the tumor could not be completely removed because it invades significant neighboring bone structures, including the jugular foreman and the sublingual neural tube. The patient died after 6 months as a result of local recurrence.

In summary, chondroblastic OS has been shown to be associated with a poor preoperative chemotherapy response and has a worse prognosis than other variants. ${ }^{24}$ However, this subtype has some particular image characteristic, which helps surgeons identify before surgery and set early therapeutic regimens.

\section{References}

1 Murphey MD, Robbin MR, McRae GA, Flemming DJ, Temple HT, Kransdorf MJ. The many faces of osteosarcoma. Radiographics 1997;17(05):1205-1231

2 Meel R, Thulkar S, Sharma MC, et al. Childhood osteosarcoma of greater wing of sphenoid: case report and review of literature. J Pediatr Hematol Oncol 2012;34(02):e59-e62

3 Mathkour M, Garces J, Beard B, Bartholomew A, Sulaiman OA, Ware ML. Primary high-grade osteosarcoma of the clivus: a case report and literature review. World Neurosurg 2016;89:730. e9-730.e13

4 Hayashi T, Kuroshima Y, Yoshida K, Kawase T, Ikeda E, Mukai M. Primary osteosarcoma of the sphenoid bone with extensive periosteal extension-case report. Neurol Med Chir (Tokyo) 2000;40(08):419-422

5 Hadley C, Gressot LV, Patel AJ, et al. Osteosarcoma of the cranial vault and skull base in pediatric patients. J Neurosurg Pediatr 2014;13(04):380-387
6 Ha PK, Eisele DW, Frassica FJ, Zahurak ML, McCarthy EF. Osteosarcoma of the head and neck: a review of the Johns Hopkins experience. Laryngoscope 1999;109(06):964-969

7 White VA, Fanning CV, Ayala AG, Raymond AK, Carrasco CH, Murray JA. Osteosarcoma and the role of fine-needle aspiration. A study of 51 cases. Cancer 1988;62(06):1238-1246

8 Daw NC, Mahmoud HH, Meyer WH, et al; Jude Children's Research Hospital Experience. Bone sarcomas of the head and neck in children: the St Jude Children's Research Hospital experience. Cancer 2000;88(09):2172-2180

9 Yarmish G, Klein MJ, Landa J, Lefkowitz RA, Hwang S. Imaging characteristics of primary osteosarcoma: nonconventional subtypes. Radiographics 2010;30(06):1653-1672

10 Haque F, Fazal ST, Ahmad SA, Abbas SZ, Naseem S. Primary osteosarcoma of the skull. Australas Radiol 2006;50(01):63-65

11 Chennupati SK, Norris R, Dunham B, Kazahaya K. Osteosarcoma of the skull base: case report and review of literature. Int J Pediatr Otorhinolaryngol 2008;72(01):115-119

12 Chen Y, Shen Q Gokavarapu S, et al. Osteosarcoma of head and neck: a retrospective study on prognostic factors from a single institute database. Oral Oncol 2016;58:1-7

13 Gadwal SR, Gannon FH, Fanburg-Smith JC, Becoskie EM, Thompson LD. Primary osteosarcoma of the head and neck in pediatric patients: a clinicopathologic study of 22 cases with a review of the literature. Cancer 2001;91(03):598-605

14 van den Berg $\mathrm{H}$, Merks JH. Incidence and grading of cranio-facial osteosarcomas. Int J Oral Maxillofac Surg 2014;43(01):7-12

15 Gangadhar K, Santhosh D. Radiopathological evaluation of primary malignant skull tumors: a review. Clin Neurol Neurosurg 2012;114(07):833-839

16 Yamada SM, Ishii Y, Yamada S, Kuribayashi S, Kumita S, Matsuno A. Advanced therapeutic strategy for radiation-induced osteosarcoma in the skull base: a case report and review. Radiat Oncol 2012;7(01):136

17 Lee YY, Van Tassel P, Nauert C, Raymond AK, Edeiken J. Craniofacial osteosarcomas: plain film, CT, and MR findings in 46 cases. AJR Am J Roentgenol 1988;150(06):1397-1402

18 Adwani D, Bhattacharya A, Adwani N, Adwani R, Sharma VW. Massive recurrent chondroblastic osteosarcoma of maxilla: a rare case report. J Clin Diagn Res 2014;8(01):288-290

19 Fox MG, Trotta BM. Osteosarcoma: review of the various types with emphasis on recent advancements in imaging. Semin Musculoskelet Radiol 2013;17(02):123-136

20 Bose B. Primary osteogenic sarcoma of the skull. Surg Neurol 2002;58(3-4):234-239, discussion 239-240

21 Geirnaerdt MJ, Bloem JL, van der Woude HJ, Taminiau AH, Nooy MA, Hogendoorn PC. Chondroblastic osteosarcoma: characterisation by gadolinium-enhanced MR imaging correlated with histopathology. Skeletal Radiol 1998;27(03):145-153

22 Yen $\mathrm{CH}$, Chang CY, Teng MM, et al. Different and identical features of chondroblastic osteosarcoma and chondrosarcoma: highlights on radiography and magnetic resonance imaging. J Chin Med Assoc 2009;72(02):76-82

23 Yakushiji T, Oka K, Sato H, et al. Characterization of chondroblastic osteosarcoma: gadolinium-enhanced versus diffusion-weighted MR imaging. J Magn Reson Imaging 2009;29(04):895-900

24 Gupta N, Rajwanshi A, Gupta P, Vaiphei K, Gupta AK. Chondroblastic osteosarcoma of the temporal region: a diagnostic dilemma. Diagn Cytopathol 2011;39(05):377-379 